\title{
Growth and Yield of Okra (Abelmoschus esculantus L.) as Influenced by Different Organic, Bioenhancers and Inorganic Techniques
}

\author{
Krapal Singh Verma*, S.S. Singh, S.P. Mishra, P. Sirothia and Mahendra Jaidiya \\ Mahatma Gandhi Chitrakoot Gramodaya Vishwa Vidyalaya, \\ Chitrakoot, District Satna (M.P.), India \\ *Corresponding author
}

\begin{abstract}
Keywords
Okra,

Bioenhancers, NPK, Yield

Article Info

Accepted:

20 July 2019

Available Online:

10 August 2019 treatment combinations involving three levels of organic manure i.e. 20 t FYM ha ${ }^{-1}, 10 \mathrm{t}$ vermicompost $\mathrm{ha}^{-1}$ and $10 \mathrm{t}$ goat manure ha ${ }^{-1}$, three levels of bio-enhancers i.e. Panchgavya (Foliar spray @ 3\% at 30, 45, 60 and 90 DAS), Beejamrit (Seed treatment @ 10\%) and Jiwamrit (500 lit./ha at each irrigation) and chemical fertilizers in three levels i.e. 0 (control), $100 \% \operatorname{RDF}\left(100,60,80 \mathrm{NPK} \mathrm{kg} \mathrm{ha}^{-1}\right)$ and 50\% RDF $\left(50,30,40 \mathrm{NPK} \mathrm{kg} \mathrm{ha}^{-}\right.$ ${ }^{1}$ ) were given in Kashi Pragati variety. Maximum plant height , number of leaves plant ${ }^{-1}$, number of internodes plant ${ }^{-1}$, Number of nodes to first flowering, Days to first flowering and Fruit yield plant ${ }^{-1}(\mathrm{~g})$ were observed by application of $10 \mathrm{t}$ Vermicompost $\mathrm{ha}^{-1}$, Panchgavya (Foliar spray @ $3 \%$ at $30,45,60$ and 90 DAS) and 100\% RDF (100,60,80 NPK kg ha $\left.{ }^{-1}\right)$ at all the growth stages .
\end{abstract}

A B S T R A C T

The experiment was carried out to find out the effect of different organic, bioenhancers and inorganic techniques on growth and yield of okra. The

\section{Introduction}

Okra [Abelmoschus esculentus (L.) Moench] has hold a key rank in vegetables it is prefered fruit vegetable cultivated richly in the subtropical, tropical and warm reagion of the world as India, Turkey, Africa and other neighbouring countries. In India, okra is a most prominent vegetable crop cultivated for its fresh soft green fruits during rainy and summer seasons. Okra is called by different regional names in different area of the world. 
It is known as Bhindi in India, Gumbo in U.S.A. and lady's finger in England. Sizeable export of okra is being done to GCC and EU markets. India is the biggest producer of okra ranked first (72.9\%) in the world (Anonymous 2017a). Okra is available throughout the year and country has the required infrastructure for export. There is still scope to expand the export to markets of GCC, EU and Singapore. Okra is widely cultivated in plans of the India. Total area covered in India by vegetable crops is 10106 thousand hectares and total production 169064 thousand metric tonnes with okra crop occupying nearly 511 thousand hectares area, production 5848.6 thousand metric tonnes and productivity of 11.40 metric tonnes/ ha (Anonymous 2017b). Okra crop covered $5.05 \%$ of total area and $3.46 \%$ of total vegetable production. In Madhya Pradesh total area under vegetable crops is 757.67 thousand hectares with production of about 15568.26 thousand metric tonnes and okra crop occupies area 27.11 thousand hectares with production 342.05 thousand metric tonnes and productivity 12.62 metric tonnes/ ha (Anonymous 2017c). Chhindwara, Jabalpur, Sagor, Hoshangabad, Tikamgarh, Ratlam, Dewas, Katni, Barwani, Gwalior, Datia, Alirajpur, Bhind, Dhar, Shivpuri and Chhatarpur are major okra producing districts in Madhya Pradesh (Anonymous 2017d).

Overexploitation of renewable and natural resources and irrational and indiscriminate application of harmful synthetic inputs as chemical fertilizers and pesticides for producing more and more in par unit area are being increasing realized to seriously spoil the ecological balance and putting the nature in jeopardy. Chemical farming is becoming major burning problem with respect to health issues of human, animal and all the leaving organisms on the earth. Poisson is spreading every side from the sky to the earth. Organic farming is not new it is being addopted from ancient time. It is a method of cultivation system which firstly aimed at cultivating the field and growing crops in such a way, as to remain the soil alive, fertile and health by use of organic wastes (crop, animal and farm wastes) and other biological things along with valuable microbes (bio fertilizers) to release macro and micro nutrients to plants for enhanced sustainable production in an eco neighbourly pollution free nature. The academic and applied researches emphasized that, lots of pesticides and fertilizer are used to increase production particularly in vegetable crops. The application of chemical fertilizers and pesticides in vegetable crops is hazardous for human health and environment. After the use of chemical fertilizers in starting, growers were happy of acquiring enhanced crop yield in the beginning. But gradually chemical fertilizers started showing their harmful effects such as polluting water basins, destroying friendly insects, microorganisms and improve susceptibility of crop for attack of diseases and pest, decreased the soil productivity and thus causing Irreversible injury to the overall system.

Among the bulky organic manures, the farm yard manure, goat manure, vermicompost and compost are the most commonly used for crop production. FYM is easily available and extensively used organic source of plant nutrient. Vermicompost is also seems to be very dynamic manure for quality and production of the crop. The combination of manures in addition with chemical fertilizers may be helpful to maintain the soil richness and health by increase content of organic carbon in soil for sustaining the productivity.

Use of Bio-enhancers is a new concept in organic agriculture. In fact these are biological preparations, prepared by animal and plant based residues through active fermentation over specific duration. The basic components are cow urine and cow dung. For 
enhancing their activities few more plant and cow products are incorporated. There are many bio enhancers, named by the developer who attempted their efficacy in crop production. Some of these bio enhancers are in common use are Panchgavaya, Jiwamrita, Amrit Pani, Bijamrita, Vermi wash etc. In fact, these are ample source of microbial consortia, macro and micronutrients and plant growth regulators including immunity boosters. Bio enhancers are used to treat seedlings / seeds, enrich soil and develop better plant vigour. If properly filtered, these could be potential tool for fertigation. As on today, numbers of bio enhancers are in use by in different prevalent organic farming systems with exciting results. No doubt modern agriculture is rooted on the application of organic farming, which plays a major role for producing the good quality and higher yield in okra per unit area. There is a necessity to explore alternative sources of nutrient which could be inexpensive, eassly available and eco-friendly so that growers may be able to lower the investment done on fertilizer along with maintaining suitable soil environmental conditions foremost to ecological sustainable farming.

\section{Materials and Methods}

A field experiment on different organic, bioenhancers and inorganic techniques on growth and yield of okra (Abelmoschus esculantus (L.) Moench) was carried out during Kharif season 2016 and 2017 at Mahatma Gandhi Chitrakoot Gramodaya Vishwa Vidyalaya, Chitrakoot, District Satna (M.P.). The research work was conducted in the Factorial Completely Randomized Block Design with three replications. Each replication was comprised of 27 treatment combinations. The treatment combinations involving three levels of organic manure i.e. $20 \mathrm{t}$ FYM ha ${ }^{-1}, 10 \mathrm{t}$ vermicompost $\mathrm{ha}^{-1}$ and $10 \mathrm{t}$ goat manure $\mathrm{ha}^{-1}$, three levels of bio-enhancers i.e. Panchgavya (Foliar spray @ 3\% at 30, 45, 60 and 90 DAS), Beejamrit (Seed treatment@ $10 \%$ ) and Jiwamrit (500 lit./ha at each irrigation) and chemical fertilizers in three levels i.e. 0 (control), $100 \%$ RDF $(100,60,80$ NPK kg ha ${ }^{-1}$ ) and 50\% RDF (50,30,40 NPK $\mathrm{kg} \mathrm{ha}^{-1}$ ) were given in Kashi Pragati (VRO-6) variety. The climate of the region is semi-arid and sub-tropical having extreme winter and summer. During the winter months, the temperature drops down to as low as $2^{\circ} \mathrm{C}$ while in the summer months the temperature extend above $47^{\circ} \mathrm{C}$, hot desiccating winds (Loo) are regular symptom during summers while, there may be infrequent spell of frost during the winter months. The soil of the investigation field was clay loam with good drainage and uniform texture with medium NPK status. Observations were recorded according to standard procedure on plant height $\mathrm{cm}$, number of leaves, number of internodes plant $^{-1}$, nodes to first flowering, days to first flowering and fruit yield plant ${ }^{-1}(\mathrm{~g})$.

\section{Results and Discussion}

The experiment was conducted to study the effect of different organic, bio-enhancers and inorganic techniques on growth and yield of okra. It is evident from the data that the significantly maximum plant height was recorded in treatment $\mathrm{O}_{2}\left(10 \mathrm{t} \mathrm{VC} \mathrm{ha}^{-1}\right)$ at 30 , 60 DAS and at final harvest. Vermicompost has the highest nutrient and was able to release these nutrients for okra plant competitively faster than goat manure. The probable reasons for increased plant height may be due to addition of organic manure to increase in cat ion exchange capacity and water holding capacity. It can also supply all the necessary primary and secondary nutrients require for plant growth i.e. height. Similar results have been reported by Premsekhar and Rajashree (2009), Sharma et al. (2014), 
Omotoso and Johnson (2015). In case of bioenhancers, the treatment $B_{1}$ (Panchgavya Foliar spray @3\% at 30, 45, 60 and 90 DAS) was recorded significantly maximum plant height at 30, 60 DAS and at final harvest. The possible reason for higher growth characters and increased height might be due to the growth enzymes present in Panchagavya which favoured rapid cell division and multiplication. The findings are in close harmony with the result of Vennila and Jayanthi (2008), Ali et al. (2011), Rajesh and Kaliyamoorthy (2013) and Yadav et al. (2017). As regards to chemical fertilizers, the treatment $\mathrm{F}_{2}(100 \%$ RDF $100,60,80 \mathrm{~kg}$ NPK $\mathrm{ha}^{-1}$ ) was observed significantly maximum plant height at 30, 60 DAS and at final harvest. This might be due to better nutritional environment in the root zone for growth and development of plant by the application of NPK. The NPK are considered as one of the major nutrients required for proper growth and development of the plant. Nitrogen is the most indispensable of all mineral nutrients for growth and development of the plant as it is the basis of fundamental constituents of all living matter. It is also a main constituent of protoplasm, cell nucleus, amino acids, proteins, chlorophyll and many other metabolic products. The biological role of nitrogen as an essential constitute of chlorophyll in harvesting solar energy, phosphorylated compound in energy transformation, nucleic acids in the transfer of genetic information and the regulation of cellular metabolism and of protein as structural units and biological catalysts is well known. Phosphorus is a constituent of adenosine tri-phosphate (ATP), the energy molecule and thus plays a vital role in the photosynthesis. Similarly, the role of potassium in stomata opening and thereby governing the entry of $\mathrm{CO}_{2}$ in widely known. Potassium plays a vital role in controlling water economy in the plants and in improving the drought tolerance. The findings are in close harmony with the result of Singh et al. (1998) and Sharma et al. (2011).

It is evident from the results that the significantly maximum leaves plant ${ }^{-1}$ was recorded in treatment $\mathrm{O}_{2}\left(10 \mathrm{t} \mathrm{VC} \mathrm{ha}^{-1}\right)$ at 30 , 60 DAS and at final harvest. The probable reasons for increased number of leaves plant ${ }^{-1}$ may be due to addition of vermicompost to increase in cat ion exchange capacity leads to increase water holding capacity in soil. It can also supply all the necessary primary and secondary nutrients require for increase number of leaves plant ${ }^{-1}$. Similar results have been reported by Nirmala and Vadivel (1999) Omotoso and Johnson (2015).

In case of bio-enhancers, the treatment $\mathrm{B}_{1}$ (Panchgavya Foliar spray @ 3\% at 30, 45, 60 and 90 DAS) was recorded significantly maximum leaves plant ${ }^{-1}$ at 30,60 DAS and at final harvest. The possible reason for this may be due to effective micro organism (EMO) cultures in panchagavya could synthesize phytohormones i.e., auxins and other growth regulators that stimulated plant growth. Chemotrophs and autotropic (ammonifers and nitrifers) present in panchagavya which colonize in the leaves increase the ammonia uptake and enhance total nitrogen supply which are stimulated in number of leaves plant $^{-1}$. The findings are in close harmony with the result of Ali et al. (2011), Rajesh and Kaliyamoorthy (2013) and Yadav et al. (2017). As regards to chemical fertilizers, the treatment $\mathrm{F}_{2}(100 \% \mathrm{RDF} 100,60,80 \mathrm{~kg}$ NPK $\mathrm{ha}^{-1}$ ) was observed significantly maximum leaves plant ${ }^{-1}$ at 30, 60 DAS and at final harvest. A proper supply of nitrogen, phosphorus and potassium through inorganic fertilizers at their recommended doses might have led to formation of soil solution rich in almost all ions required to be essentially to the plants. It is again an established fact that among other things, the nutrients acquisition power of a plant greatly depends on the 
concentration of the ions in soil solution. It can therefore, be assumed that the plants growing in the plots with all main nutrients enjoyed a situation congenial for their growth and development. Similar results have been reported by Singh et al. (1998).

It is evident from the data that the significantly maximum internodes plant ${ }^{-1}$ was recorded in treatment $\mathrm{O}_{2}\left(10 \mathrm{t} \mathrm{VC} \mathrm{ha}^{-1}\right)$ at 30, 60 DAS and at final harvest. The probable reasons for increased number of internodes plant $^{-1}$ may be due to cumulative effect of continuous supply of nutrients, vitamins and growth promoting substances present in vermicompost which ultimately lead to enhanced cell division. These results were in close conformity with the findings of Sharma et al. (2014).

In case of bio-enhancers, the treatment $\mathrm{B}_{1}$ (Panchgavya Foliar spray @ 3\% at 30, 45, 60 and 90 DAS) was recorded significantly maximum internodes plant $^{-1}$. The possible reason for this may be due to effective micro organism (EMO) cultures in panchagavya could synthesize phytohormones i.e., auxins and other growth regulators that stimulated plant growth. The findings are in close harmony with the result of Vennila and Jayanthi (2008), Ali et al. (2011), Rajesh and Kaliyamoorthy (2013) and Yadav et al. (2017). As regards to chemical fertilizers, the treatment $\mathrm{F}_{2}(100 \%$ RDF $100,60,80 \mathrm{~kg}$ NPK $\mathrm{ha}^{-1}$ ) was observed significantly maximum internodes plant ${ }^{-1}$ at 30,60 DAS and at final harvest.

A proper supply of nitrogen, phosphorus and potassium through inorganic fertilizers at their recommended doses might have led to formation of soil solution rich in almost all ions required to be essentially to the plants. It is again an established fact that among other things, the nutrients acquisition power of a plant greatly depends on the concentration of the ions in soil solution. It can therefore, be assumed that the plants growing in the plots with all main nutrients enjoyed a situation congenial for their growth and development. Similar results have been reported by Sharma et al. (2011).

It is evident that the node to first flowering was significantly influenced by different treatments. Significantly minimum node to first flowering was obtained in treatment $\mathrm{O}_{3}$ $\left(10 \mathrm{t} \mathrm{GM} \mathrm{ha}^{-1}\right)$. The probable reasons for increased node to first flowering may be due to cumulative effect of continuous supply of nutrients, vitamins and growth promoting substances present in vermicompost which ultimately lead to enhanced cell division and delay first flowering. These results were in close conformity with the findings of Nirmala and Vadivel (1999). Significantly minimum was noted in treatment $\mathrm{B}_{2}$ (Beejamrit (Seed treatment@10\%).

The probable reasons for this beneficial microorganism from panchagavya and their establishment in the soil improved the sustainability of agriculture as the microorganisms present in the rhizospheres environment around the roots influence the plant growth and crop yield. As regards to chemical fertilizers, significantly minimum node to first flowering was obtained in treatment $\mathrm{F}_{1}$ (control).

A proper supply of nitrogen, phosphorus and potassium through inorganic fertilizers at their recommended doses might have led to formation of soil solution rich in almost all ions required to be essentially to the plants. It is again an established fact that among other things, the nutrients acquisition power of a plant greatly depends on the concentration of the ions in soil solution. It can therefore, be assumed that the plants growing in the plots with all main nutrients enjoyed a situation congenial for their growth and development. 
Table.1 Effect of different organic manures, bio-enhancers and chemical fertilizers on different growth parameters of okra

\begin{tabular}{|c|c|c|c|c|c|c|c|c|c|c|c|c|c|c|c|}
\hline \multirow[t]{2}{*}{ Treatment } & \multicolumn{3}{|c|}{ Plant height $(\mathrm{cm})$ at } & \multicolumn{3}{|c|}{ Number of leaves plant ${ }^{-1}$ at } & \multicolumn{3}{|c|}{ Number of internodes plant ${ }^{-1}$ at } & \multicolumn{3}{|c|}{$\begin{array}{c}\text { Number of nodes to first } \\
\text { flowering at }\end{array}$} & \multicolumn{3}{|c|}{ Days to first flowering at } \\
\hline & 30 DAS & $\begin{array}{c}\text { 60 } \\
\text { DAS }\end{array}$ & Harvesting & 30 DAS & 60 DAS & Harvesting & 30 DAS & 60 DAS & Harvesting & $\begin{array}{c}1^{\text {st }} \\
\text { year }\end{array}$ & $2^{\text {nd }}$ year & Pooled & $1^{\text {st }}$ year & $2^{\text {nd }}$ year & Pooled \\
\hline$O_{1}(20$ t FYM/ha $)$ & 25.79 & 73.91 & 124.73 & 9.81 & 24.40 & 32.94 & 9.81 & 19.37 & 33.15 & 4.71 & 5.36 & 4.96 & 42.43 & 44.08 & 43.01 \\
\hline $\mathrm{O}_{2}(10 \mathrm{t} \mathrm{VC/ha})$ & 27.92 & 80.42 & 132.61 & 12.88 & 26.31 & 35.39 & 12.88 & 21.40 & 35.57 & 4.98 & 5.81 & 5.23 & 44.22 & 46.39 & 44.80 \\
\hline $\mathrm{O}_{3}(10 \mathrm{t} \mathrm{GM} / \mathrm{ha})$ & 24.47 & 67.59 & 117.89 & 8.09 & 22.37 & 31.28 & 8.09 & 17.66 & 31.46 & 4.55 & 5.07 & 4.80 & 40.66 & 42.01 & 41.25 \\
\hline SEm \pm & 0.10 & 0.09 & 0.09 & 0.05 & 0.05 & 0.04 & 0.05 & 0.06 & 0.07 & 0.03 & 0.03 & 0.03 & 0.06 & 0.06 & 0.06 \\
\hline $\mathrm{CD}_{5 \%}$ & 0.29 & 0.25 & 0.27 & 0.15 & 0.15 & 0.12 & 0.15 & 0.16 & 0.20 & 0.09 & 0.09 & 0.09 & 0.17 & 0.17 & 0.17 \\
\hline $\begin{array}{l}\mathrm{B}_{1} \text { (Panchgavya } \\
\text { (Foliar spray @ } \mathbf{3 \%} \\
\text { at 30, 45, } 60 \text { and } 90 \\
\text { DAS) }\end{array}$ & 26.95 & 76.58 & 127.85 & 11.05 & 25.19 & 33.94 & 11.05 & 20.26 & 34.12 & 4.82 & 5.57 & 5.07 & 43.08 & 45.14 & 43.66 \\
\hline $\begin{array}{l}B_{2} \text { (Beejamrit (Seed } \\
\text { treatment @ 10\%) }\end{array}$ & 25.38 & 71.69 & 122.69 & 9.52 & 23.63 & 32.54 & 9.52 & 18.85 & 32.72 & 4.68 & 5.27 & 4.93 & 41.84 & 43.27 & 42.42 \\
\hline $\begin{array}{lrr}\mathbf{B}_{3} & \text { (Jiwamrit } \\
\text { (Applied with } & \text { every } \\
\text { irrigation } & 0 & \mathbf{5 0 0} \\
\text { lit./ha) } & & \end{array}$ & 25.85 & 73.65 & 124.68 & 10.20 & 24.25 & 33.13 & 10.20 & 19.33 & 33.34 & 4.74 & 5.40 & 4.99 & 42.39 & 44.08 & 42.97 \\
\hline $\operatorname{SEm} \pm$ & 0.10 & 0.09 & 0.09 & 0.05 & 0.05 & 0.04 & 0.05 & 0.06 & 0.07 & $\mathbf{0 . 0 3}$ & 0.03 & 0.03 & 0.06 & 0.06 & 0.06 \\
\hline $\mathrm{CD}_{5 \%}$ & 0.29 & 0.25 & 0.27 & 0.15 & 0.15 & 0.12 & 0.15 & 0.16 & 0.20 & 0.09 & 0.09 & 0.09 & 0.17 & 0.17 & 0.17 \\
\hline$F_{1}($ Control $)$ & 23.74 & 64.62 & 113.98 & 6.86 & 21.57 & 30.06 & 6.86 & 16.76 & 30.26 & 4.41 & 4.93 & 4.66 & 39.93 & 41.10 & 40.51 \\
\hline $\begin{array}{l}F_{2}(R D F \quad(100,60,80 \\
\mathrm{kg} \text { NPK /ha) }\end{array}$ & 28.54 & 84.49 & 136.51 & 14.62 & 27.42 & 36.95 & 14.62 & 22.37 & 37.14 & 5.15 & 6.06 & 5.40 & 45.11 & 47.69 & 45.70 \\
\hline $\begin{array}{llr}F_{3}(50 \% & \text { of } & \text { RDF } \\
(50,30,40 & \mathrm{kg} & \text { NPK } / \mathrm{ha})\end{array}$ & 25.90 & 72.81 & 124.74 & 9.30 & 24.08 & 32.60 & 9.30 & 19.30 & 32.78 & 4.68 & 5.26 & 4.93 & 42.27 & 43.70 & 42.85 \\
\hline SEm \pm & 0.10 & 0.09 & 0.09 & 0.05 & 0.05 & 0.04 & 0.05 & 0.06 & 0.07 & 0.03 & 0.03 & 0.03 & 0.06 & 0.06 & 0.06 \\
\hline $\mathrm{CD}_{5 \%}$ & 0.29 & 0.25 & 0.27 & 0.15 & 0.15 & 0.12 & 0.15 & 0.16 & 0.20 & & & & 0.17 & 0.17 & 0.17 \\
\hline
\end{tabular}


It is evident from the results that the days to first flowering was significantly influenced by different treatments. Significantly early days to first flowering was obtained in treatment $\mathrm{O}_{3}\left(10 \mathrm{t} \mathrm{GM} \mathrm{ha}^{-1}\right)$. The probable reasons for increased days to first flowering may be due to cumulative effect of continuous supply of nutrients, vitamins and growth promoting substances present in vermicompost which ultimately lead to enhanced cell division and delay first flowering. These results were in close conformity with the findings of Nirmala and Vadivel (1999), Sharma et al. (2014). In case of bio-enhancers, significantly early days to first flowering was noted in treatment $B_{3}$ (Jiwamrit (Applied with every irrigation@ 500 lit./ha). The probable reasons for this beneficial microorganism from panchagavya and their establishment in the soil improved the sustainability of agriculture as the microorganisms present in the rhizospheres environment around the roots influence the plant growth and crop yield. As regards to chemical fertilizers, significantly early days to first flowering was obtained in treatment $F_{1}$ (control). The reason for this could again be ascribed to the role which might have been played by the nutrients supplied to the plants. It is relevant to mention here that adequate supply of phosphorus to plants play a unique role in laying down the floral primordial. These results were in close conformity with the findings of Singh et al. (1998a) and Singh et al. (2015).

Maximum fruit yield plant ${ }^{-1}$ was observed in the treatment $\mathrm{O}_{2}\left(10 \mathrm{t} \mathrm{VC} \mathrm{ha}^{-1}\right)$. These results were corroborated with the findings of Sharma et al. (2014) . In case of bioenhancers, the treatment $\mathrm{B}_{1}$ (Panchgavya Foliar spray @3\% at 30, 45, 60 and 90 DAS) was recorded significantly maximum. In Panchagavya, Effective Micro Organisms (EMO) were the mixed culture of naturally occurring, beneficial microbes mostly lactic acid bacteria (Lactobacillus), yeast
(Saccharomyces), actinomyces (Streptomyces), photosynthetic bacteria (Rhodopsuedomonas) and certain fungi (Aspergillus) and that improved the fruits yield plant ${ }^{-1}$. These results were corroborated with the findings of Ali et al. (2011). As regards to chemical fertilizers, significantly maximum fruits yield plant ${ }^{-1}$ was obtained in treatment $\mathrm{F}_{2}$ (100\% RDF 100, 60, $80 \mathrm{~kg}$ NPK $\left.\mathrm{ha}^{-1}\right)$. The application of NPK favored the metabolic and auxin activities in plant and ultimately resulted in increased fruit yield per plant. These findings are similar of those Singh et al. (2015).

\section{References}

Ali, M. N., Ghatak, S. and Ragul, T. (2011). Biochemical analysis of Panchagavya and Sanjibani and their effect in crop yield and soil health. Journal of Crop and Weed. 7 (2): 84-86.

Anonymous (2017a). Horticulture statistics at a glance 2017. Published by Department of Agriculture, Cooperation and Farmers Walfare, Ministry of Agriculture and Farmers Walfare, Govt. of India. pp. 458.

Anonymous (2017b). Horticulture statistics at a glance 2017. Published by Department of Agriculture, Cooperation and Farmers Walfare, Ministry of Agriculture and Farmers Walfare, Govt. of India. pp. 141 and 511.

Anonymous (2017d). Horticulture statistics at a glance 2017. Published by Department of Agriculture, Cooperation and Farmers Walfare, Ministry of Agriculture and Farmers Walfare, Govt. of India. pp. 308.

Premsekhar, M. and Rajashree, V. (2009). Influence of organic manures on growth, yield and quality of okra. American-Eurasian Journal of Sustainable Agriculture. 3 (1): 6-8.

Rajesh, M. and Kaliyamoorthy, Jayakumar 
(2013). Changes in morphological, biochemical and yield parameters of Abelmoschus esculents (L.) Moench due to Panchagavya spray. International Journal of Modern Plant \& Animal Sciences. 1 (2): 82-95.

Sharma, D. P., Prajapati, Jagat Lal and Tiwari, Akhilesh (2014). Effect of NPK, vermicompost and vermiwash on growth and yield of Okra. International Journal of Basic and Applied Agricultural Research. 12 (1): 5-8.

Sharma, T. R., Pandey, A. K. Updhyaya, S. D. and Agrawal, S. B. (2011). Effect of sources of nutrients and their levels on yield, quality and economics of summer season okra. Indian Journal of Horticulture. 68 (4): 498-502.

Singh, K. V., Anuj, K., Kumar, M., Soni, S., Kumar, A. and Singh, M. K. (2015). Response of different organic and inorganic fertilizers on growth and yield of okra (Abelmoschus esculentus (L.) Moench). Ann. Hort. 8 (1): 107-109.

Singh, R. P., Rajput, C. B. S. and Chaurasia, S. N. S. (1998). Effect of different levels and methods of potassium application on growth and green pod yield of okra cv. Parbhani Kranti. Haryana J. Hort. Sci. 27 (4): 288-292.

Vennila, C. and Jayanthi, C. (2008). Response of okra to integrated nutrient management. J. Soils Crops, 18: 36-40.

Yadav, G. L., Singh, S. P., Jitarwal, O. P., Yadav, V. K. and Choudhary, R. (2017). Effect of nitrogen and bioorganics on growth and yield of okra [Abelmoschus esculentus (L.) Moench]. Chemical Science Review and Letters. 6 (23): 1515-1519.

\section{How to cite this article:}

Krapal Singh Verma, S.S. Singh, P. Sirothia and Mahendra Jaidiya. 2019. Growth and Yield of Okra (Abelmoschus esculantus L.) is Influenced by Different Organic, Bioenhancers and Inorganic Techniques. Int.J.Curr.Microbiol.App.Sci. 8(08): 2343-2350.

doi: https://doi.org/10.20546/ijcmas.2019.808.271 